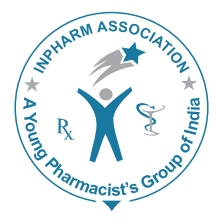

\title{
Atypical antipsychotic drugs in India: A scientometric study during 1998-2013
}

\author{
M Ahmed ${ }^{1}$, Ritu Gupta ${ }^{2}$, BM Gupta ${ }^{3^{*}}$ \\ ${ }^{1}$ Phcog. Net and SciBiolMed, Bangalore, Karnataka, India, ${ }^{2}$ Sri Vankateshwar University, Meerut, \\ Uttar Pradesh, India, ${ }^{3}$ Panchkula, Haryana, India
}

\begin{abstract}
Present a bibliometric analysis of 1432 publications in Indian research in atypical antipsychotic drugs during 1998-2013, using publications indexed in Scopus database. The study identified the global publication share and rank of Indian research output among the 15 most productive countries and examined the distribution of citations of the Indian research output, the share of international collaborative publications in Indian publication output and identification of the leading India's collaborating partners, the distribution of Indian research output by broad subject areas, by individual drugs and by disease; publication productivity and the citation impact of leading Indian institutions; the media of communication and the characteristics of the high cited publications.
\end{abstract}

Key words: Atypical antipsychotic drugs, India, publications, scientometrics

\section{INTRODUCTION}

Mental disorders are classified as a psychological condition marked primarily by sufficient disorganization of personality, mind, and emotions to seriously impair the normal psychological and often social functioning of the individual. Antipsychotic medications, introduced in the 1950 's, is also widely used to treat some types of mental distress, mainly schizophrenia and manic depression (bipolar disorder), agitation associated with dementia, anxiety disorder, autism spectrum disorder, obsessive-

\begin{tabular}{|c|l|}
\hline \multicolumn{2}{|c|}{ Access this article online } \\
\hline \multicolumn{3}{|c|}{ Wournal Sponsor } & $\begin{array}{l}\text { Website: } \\
\text { www.jyoungpharm.org }\end{array}$ \\
\cline { 2 - 2 } & \\
\cline { 2 - 2 } www.phcognet & DOI: \\
& $10.5530 /$ /jyp.2014.2.3 \\
& \\
\hline
\end{tabular}

compulsive disorders, etc. ${ }^{1}$ Antipsychotic medications cannot "cure" the illness, but they can take away many of the symptoms or make them milder. In some cases, they can shorten the course of an episode of the illness as well. The first antipsychotic medications were introduced in the 1950s. Antipsychotic medications have helped many patients with psychosis lead a more normal and fulfilling life by alleviating such symptoms as hallucinations, both visual and auditory and paranoid thoughts. However, the early antipsychotic medications often have unpleasant side-effects, such as muscle stiffness, tremor, and abnormal movements, leading researchers to continue their search for better drugs. ${ }^{2}$

Antipsychotic medications are thought to work by altering the effect of certain chemicals in the brain, called dopamine, serotonin, noradrenaline, and acetylcholine. These chemicals have the effect of changing your behavior, mood, and emotions. Dopamine is the main chemical 
that these medicines have an effect on. By altering the effects of these chemicals in the brain they can suppress or prevent you from experiencing: Hallucinations (such as hearing voices), delusions (having ideas not based on reality), thought disorder and extreme mood swings that are associated with bipolar disorder. ${ }^{3}$ The development of antipsychotics over the last 60 years has come full circle. The first wave of effective antipsychotics was serendipitously discovered in the 1950s and had multiple mechanisms of action. The second wave (e.g. haloperidol) was rationally developed to have a specific and selective mechanism of action-dopamine D2 receptor blockade. The third wave completed the circle in that the newest antipsychotics ("atypical" antipsychotics) also have multiple mechanisms of action; specifically, they combine blockade of certain subtypes of serotonin (five hydroxytryptamine) receptors and blockade of the $\mathrm{D} 2$ receptor. In contrast to the first wave, the third wave was rationally designed to have multiple mechanisms of action. ${ }^{4}$

The 1990s saw the development of several new drugs called "atypical antipsychotics (AAP)" or "second generation antipsychotics" (SGAs) for controlling mental diseases. Because they have fewer side-effects than the older drugs, today they are often used as a first-line treatment. The first AAP, clozapine (clozaril), was introduced in the United States in 1989. Since then, six other AAPs have been introduced: Risperidone (1993), olanzapine (1996), quetiapine (1997), ziprasidone (2001), aripiprazole (2002), and paliperidone (2006), and several others followed them. ${ }^{5}$ The group of atypical antipsychotic drugs (AADs) also have received regulatory approval (e.g. by the Food and Drug Administration of the US, the Therapeutic Goods Administration, of Australia, the Medicines and Healthcare products Regulatory Agency of the UK) for schizophrenia, bipolar disorder, autism and as an adjunct in major depressive disorder. ${ }^{5}$

The advances achieved in the field of antipsychotic drugs in the past 20 years have been incredibly important, with the clinical introduction of numerous SGAs (risperidone, olanzapine, quetiapine, ziprasidone, aripiprazole, etc.), which have notably improved the quality of life of psychotic patients and have contributed decisively to weakening the stigmatization that has traditionally accompanied psychiatric attention. With the clinical introduction of the new SGAs, research related to these drugs has advanced considerably, and this has led to a considerable growth in the publications on these drugs world-wide as well as in India. ${ }^{6}$ The present study, therefore, quantitative analyzes the trends of research and characteristics of literature in the area of AADs in India.

\section{Literature review}

A few quantitative studies have been carried out in AADs research in some countries. Lopez-Munoz et al. performed a bibliometric study of 438 scientific publications in Australia ${ }^{7}$ during 1993-2011, 656 scientific publications from Spain ${ }^{8}$ during 1998-2011, 326 publications in South Korea ${ }^{6}$ during 1993-2011 and 44 publications in Hong Kong ${ }^{9}$ during 1993-2001 on AADs, using Embase and Medline databases. The authors applied some bibliometric indicators of paper production and dispersion with Price's law and Bradford's law, respectively. They also calculated the participation index of the different countries and correlated the bibliometric data with some social and health data. They have also identified the most widely used AADs.

Furthermore, few bibliometric analysis of Indian research has been carried out on few mental health diseases, such as dementia ${ }^{10}$ research during 2002-2011 by Gupta, Harkaur and Kshitig, Alzheimer's disease, ${ }^{11}$ Parkinson's disease, ${ }^{12}$ epilepsy research ${ }^{13}$ and schizophrenia ${ }^{14}$ research by Gupta and Bala during 2002-2011, using Scopus database. Research in these publications have been carried output on different parameters including the growth, global publication share, citation impact, share of international collaborative publications, contribution of major collaborative partners, contribution of various subject fields and by type of research, productivity and citation impact of most productive Indian organizations and authors and pattern of research communication.

\section{Objectives}

The main objectives of the present study are to analyze the research performance of Indian research in AADs during 1998-2013, based on publications indexed in Scopus database. In particular, the study focuses on the following objectives: (i) To study the global research output and its growth; (ii) to study the contribution and citation impact of top 15 most productive countries; (iii) to examine the distribution of citations of the Indian research output; (iv) to study the share of international collaboration publications in Indian publication output and by the leading collaborating partners; (v) to study the distribution of Indian research output by broad subject areas; (vi) to study the distribution of Indian publications output by individual drugs and by disease; (vii) to study the publication productivity and the citation impact of leading institutions; (viii) to study the media of communication; and (ix) to study the characteristics of the high cited publications. 


\section{METHODOLOGY}

The study retrieved the global publication data and of top 15 most productive countries in AADs from the Scopus database (http://www.Scopus.com) for 16 years during 1998-2013. The keyword "AAP" and "names of 15 AADs" were used in "title, abstract and keyword" field and "1998-2013" in the time field (as shown in following search strategy) was used for searching the main publication data used in the study and this become the main search string. Similar strings were used to generate publications output data of top 15 countries, including India by restricting the main search strategy to particular "country code" tag. For generating citation impact data, the 3 years, 2 years, 1 year citation window was used for publications during 1998-2011, 2012 and 2013. And the citation time was restricted until the end of April 2014. For analyzing institutional and journals output, the main search strategy was restricted to "institutional tag" and "journal tag" to generate the desired output.

[TITLE-ABS-KEY (“AAP”) or TITLE-ABS-KEY (clozapine or risperidone or quetiapine) or TITLEABS-KEY (aripiprazole or amisulpride or ziprasidone) or TITLE-ABS-KEY (paliperidone or asenapine or iloperidone) or TITLE-ABS-KEY (blonanserin or zotepine or lurasidone) or TITLE-ABS-KEY (sertindole or perospirone or olanzapine)] and PUB YEAR $>1997$ and PUB YEAR <2014.

\section{ANALYSIS}

\section{Global publication output, share, and rank}

The global publication share of top 15 most productive countries in AADs in India varied from 1.79\% to 36.01\% during 1998-2013, with USA occupying the first rank and contributing the largest publication share $(36.01 \%)$, followed by UK $\left(9.06 \%, 2^{\text {nd }}\right.$ rank), Germany $(7.17 \%$, $3^{\text {rd }}$ rank), Canada $\left(5.56 \%, 4^{\text {th }}\right.$ rank), Italy $\left(4.68 \%, 5^{\text {th }}\right.$ rank), Germany, France, Italy and India (from $4.05 \%$ to $4.63 \%$ publication share and rank from $6^{\text {th }}$ to $\left.9^{\text {th }}\right)$, India and The Netherlands (from $2.5 \%$ to $2.86 \%$ publication share and rank from $10^{\text {th }}$ to $11^{\text {th }}$ ) and Turkey, China, Switzerland and Belgium (from $1.60 \%$ to $1.90 \%$ publication share and rank from $12^{\text {th }}$ to $15^{\text {th }}$ ). The global publication share has witnessed the largest increase of $2.90 \%$ in India, followed by China (1.64\%), Turkey (1.42\%), Italy (1.21\%), Australia (1.12\%), Japan (1.06\%), Belgium (1.04\%), Spain (1.01\%), Canada $(0.8 \%)$, The Netherlands $(0.6 \%)$ and Switzerland $(0.28 \%)$, as against decrease by $1.08 \%$ in USA, followed by Germany $(0.85 \%)$, France $(0.32 \%)$ and UK $(0.07 \%)$ from 1998-2005 to 2006-2013. The countries which have increased their global publication rank among 15 most productive countries are: India (from $12^{\text {th }}$ to $8^{\text {th }}$ ), China (from $15^{\text {th }}$ to $13^{\text {th }}$ ), Turkey (from $13^{\text {th }}$ to $12^{\text {th }}$ ), Australia (from $8^{\text {th }}$ to $7^{\text {th }}$ ) and Spain (from $7^{\text {th }}$ to $6^{\text {th }}$ ), as against decrease in France (from 6th to $\left.10^{\text {th }}\right)$, Switzerland $\left(11^{\text {th }}\right.$ to $15^{\text {th }}$ ) and The Netherlands (from $10^{\text {th }}$ to $11^{\text {th }}$ ) from 1998-2005 to 2006-2013 (Table 1).

\section{Indian publications output and citation impact}

India has published 1432 publications in AADs during 1998-2013, which increased from nine publications in 1998-2016 publications in 2013, witnessing an annual average growth rate of $22.76 \%$. India's cumulative publication output in antipsychotic drugs increased from 183 publications during 1998-2005 to 1249 during 2006-2013, witnessing a growth rate of $23.71 \%$. Compared to this, world has published 50119 publications in AADs during 1998-2013, which increased from 1325 in 1998-4006 publications in 2013, witnessing an annual average growth rate of $7.50 \%$. The average citation impact (on 3 years citation window) made by all Indian publications in AADs during 1998-2013 was 2.43, which decreased from 3.14 during 1998-2005 to 2.32 during 2006-2013 (Table 2). The total Indian output (1432 publications) consisted of 904 articles (63.13\%), 303 letters $(21.16 \%), 180$ reviews $(12.57 \%), 18$ notes $(1.26 \%), 12$ conference publications $(0.84 \%), 8$ editorials $(0.56 \%), 6$ short surveys (0.42\%), and 1 erratum (0.07\%) during 1998-2013.

\section{Citation pattern of Indian research output}

Citations of publications since their publication were examined from 1998 to April 2014. During this period, 9046 citations were received by 1432 publications, and the average rate of citations per publication is $6.32 .35 .89 \%$ of the total publications did not get any citations (zero citation) and the rest of the $64.11 \%$ publications were cited one or more times. Of the total cited publications, $0.84 \%$ publications (receiving more than 100 citations) contributed 22.71\% citations share, $0.56 \%$ publications (receiving citations from 51 to 100 ) contributed $5.83 \%$ citations share, $2.58 \%$ publications (receiving citations from 31 to 50 ) contributed $15.65 \%$ citations share, $11.03 \%$ publications (receiving citations from 11 to 30 ) contributed $30.07 \%$ citations, and the rest $49.090 \%$ publications (receiving citations from 1 to 10 ) contributed $35.89 \%$ citations share (Table 3).

\section{International collaboration}

The share of international collaborative publications in total Indian publication output in AADs during was

Journal of Young Pharmacists Vol 6 • Issue 2 • Apr-Jun 2014 
Table 1: Global publication output, share and rank in AADs in India, 1998-2013

\begin{tabular}{|c|c|c|c|c|c|c|c|c|c|}
\hline \multirow[t]{2}{*}{ Country } & \multicolumn{3}{|c|}{ Number of publications } & \multicolumn{3}{|c|}{ Global share of publications } & \multicolumn{3}{|c|}{ Global publication rank } \\
\hline & 1998-2005 & 2006-2013 & 1998-2013 & 1998-2005 & 2006-2013 & 1998-2013 & 1998-2005 & 2006-2013 & 1998-2013 \\
\hline USA & 6671 & 11378 & 18049 & 36.70 & 35.62 & 36.01 & 1 & 1 & 1 \\
\hline UK & 1656 & 2886 & 4542 & 9.11 & 9.04 & 9.06 & 2 & 2 & 2 \\
\hline Germany & 1402 & 2191 & 3593 & 7.71 & 6.86 & 7.17 & 3 & 3 & 3 \\
\hline Canada & 918 & 1869 & 2787 & 5.05 & 5.85 & 5.56 & 4 & 4 & 4 \\
\hline Italy & 711 & 1635 & 2346 & 3.91 & 5.12 & 4.68 & 5 & 5 & 5 \\
\hline Spain & 551 & 1292 & 1843 & 3.03 & 4.04 & 3.68 & 7 & 6 & 6 \\
\hline Australia & 526 & 1282 & 1808 & 2.89 & 4.01 & 3.61 & 8 & 7 & 7 \\
\hline Japan & 501 & 1221 & 1722 & 2.76 & 3.82 & 3.44 & 9 & 9 & 8 \\
\hline France & 650 & 1042 & 1692 & 3.58 & 3.26 & 3.38 & 6 & 10 & 9 \\
\hline India & 183 & 1249 & 1432 & 1.01 & 3.91 & 2.86 & 12 & 8 & 10 \\
\hline Netherlands & 385 & 869 & 1254 & 2.12 & 2.72 & 2.50 & 10 & 11 & 11 \\
\hline Turkey & 181 & 773 & 954 & 1.00 & 2.42 & 1.90 & 13 & 12 & 12 \\
\hline China & 142 & 772 & 914 & 0.78 & 2.42 & 1.82 & 15 & 13 & 13 \\
\hline Switzerland & 275 & 572 & 847 & 1.51 & 1.79 & 1.69 & 11 & 15 & 14 \\
\hline Belgium & 170 & 634 & 804 & 0.94 & 1.98 & 1.60 & 14 & 14 & 15 \\
\hline World & 18178 & 31941 & 50119 & & & & & & \\
\hline
\end{tabular}

AADs: Atypical antipsychotic drugs

Table 2: World and Indian publications and citation impact in AADs in India, 1998-2013

\begin{tabular}{lcccccc}
\hline Period & World & \multicolumn{5}{c}{ India } \\
\cline { 3 - 7 } & TP & TP & TC & ACPP & ICP & $\%$ ICP \\
\hline 1998 & 1325 & 9 & 23 & 2.56 & & 0.00 \\
1999 & 1563 & 11 & 29 & 2.64 & 3 & 27.27 \\
2000 & 1658 & 12 & 11 & 0.92 & & 0.00 \\
2001 & 1837 & 16 & 55 & 3.44 & 2 & 12.50 \\
2002 & 2278 & 17 & 40 & 2.35 & 1 & 5.88 \\
2003 & 2809 & 27 & 87 & 3.22 & 5 & 18.52 \\
2004 & 3222 & 40 & 103 & 2.58 & 5 & 12.50 \\
2005 & 3486 & 51 & 226 & 4.43 & 9 & 17.65 \\
2006 & 3640 & 77 & 212 & 2.75 & 15 & 19.48 \\
2007 & 4137 & 96 & 334 & 3.48 & 15 & 15.63 \\
2008 & 4103 & 101 & 516 & 5.11 & 17 & 16.83 \\
2009 & 4000 & 153 & 393 & 2.57 & 19 & 12.42 \\
2010 & 3939 & 156 & 425 & 2.72 & 18 & 11.54 \\
2011 & 4083 & 222 & 675 & 3.04 & 22 & 9.91 \\
2012 & 4033 & 228 & 241 & 1.06 & 16 & 7.02 \\
2013 & 4006 & 216 & 105 & 0.49 & 14 & 6.48 \\
$1998-2005$ & 18178 & 183 & 574 & 3.14 & 25 & 13.66 \\
$2006-2013$ & 31941 & 1249 & 2901 & 2.32 & 136 & 10.89 \\
$1998-2013$ & 50119 & 1432 & 3475 & 2.43 & 161 & 11.24 \\
\hline TP: & & & & & &
\end{tabular}

TP: Total publications, TC: Total citations, ACPP: Average citation per paper, AADs: Atypical antipsychotic drugs

$11.24 \%$ (161 publications) during 1998-2013, which decreased from $13.66 \%$ (25 publications) during 1998-2005 to $10.89 \%$ (136 publications) during 2006-2013. In all 83 foreign countries collaborated with India, as reflected in India's collaborative publications during 1998-2013. During this period, United States contributed the largest share $(49.69 \%)$ of international collaborative publications with India, followed by UK (26.09\%), Australia (16.77\%), Canada (8.70\%), Malaysia (7.45\%), Israel (6.83\%), China (6.83\%), Germany, South Korea, Switzerland and
Table 3: Citations received by Indian publications in AADs in India, 1998-2013

\begin{tabular}{lcccc}
$\begin{array}{l}\text { Number of } \\
\text { citations }\end{array}$ & $\begin{array}{c}\text { Number of } \\
\text { publications }\end{array}$ & $\begin{array}{c}\text { Total } \\
\text { citations }\end{array}$ & $\begin{array}{c}\% \\
\text { publications }\end{array}$ & $\begin{array}{c}\% \\
\text { citations }\end{array}$ \\
\hline 0 & 514 & 0 & 35.89 & 0 \\
$1-10$ & 703 & 2329 & 49.09 & 25.75 \\
$11-30$ & 158 & 2720 & 11.03 & 30.07 \\
$31-50$ & 37 & 1416 & 2.58 & 15.65 \\
$51-100$ & 8 & 527 & 0.56 & 5.83 \\
$>100$ & 12 & 2054 & 0.84 & 22.71 \\
Total & 1432 & 9046 & 100.00 & 100.00 \\
\hline
\end{tabular}

AADs: Atypical antipsychotic drugs

Thailand (6.21\% each), Japan and Singapore (5.59\% each), etc. India's international collaborative publication share has increased by $10.29 \%$ in Canada, followed by Malaysia (7.45\%), Switzerland and Thailand (7.35\% each), Japan and Singapore (6.62\% each), China (3.35\%), South Korea (2.62\%), UK (2.47\%0, USA (2.0\%) and Australia (0.91\%), as against decrease in Israel by $6.12 \%$ and in Germany by $2.12 \%$ from 1998-2005 to 2006-2013 (Table 4).

\section{Subject-wise distribution}

The India's publication output in AADs research during 1998-2013 has been published in the context of six sub-fields (as reflected in Scopus database classification), with highest publication output coming from medicine (871 publications, $60.82 \%$ share), followed by pharmacology, toxicology and pharmaceutics (536 publications, $37.43 \%$ ), neurosciences (177 publications, $12.36 \%$ ), chemistry (159 publications, $11.10 \%)$, biochemistry, genetics and molecular biology (147 publications, $10.27 \%$ ) and psychiatry and psychology (101 publications, 7.05\%) during 1998-2013. 
On analyzing the trends in AADs research in India using activity index, it was found that research activity has increased in medicine (activity index from 59.29 to 99.38), pharmacology, toxicology and pharmaceutics (activity index from 79.06 to 100.53), neurosciences (activity index from 48.63 to 91.33 ) and chemistry (from 88.59 to 106.72), as against decrease in biochemistry, genetics and molecular activity (activity index from 127.76 to 100.61 ) and psychiatry and psychology (activity index from 185.94 to 86.27 ). In terms of citation impact per paper, it was found that neurosciences had scored the highest citation impact (3.56), followed by psychiatry or psychology (3.02), pharmacology, toxicology and pharmaceutics (2.95), biochemistry, genetics and molecular biology (2.90), chemistry (2.70) and medicine (2.06) during 1998-2013 (Table 5).

\section{Drug-wise distribution of publications}

Of the total Indian publications in AADs researched, $603(42.11 \%)$ related to olanzapine, $543(37.92 \%)$ to risperidone, $359(25.07 \%)$ were related to clozapine, $244(17.04 \%)$ to quetiapine, $162(11.31 \%)$ to aripiprazole, $111(7.75 \%)$ to ziprasidone, $99(6.91 \%)$ to amisulpride, $46(3.21 \%)$ to paliperidone, $20(1.40 \%)$ to asenapine,
$14(0.98 \%)$ to iloperidone, $9(0.63 \%)$ to zotepine, $5(0.35 \%)$ to blonanserine, $4(0.24 \%)$ each to lurasidone and perospirone during 1998-2013. The research interest in the use of these drugs have increased in quetiapine (from $8.74 \%$ to $18.25 \%$ ), aripiprazole (from $2.19 \%$ to $12.65 \%$ ), ziprasidone (from $7.10 \%$ to $7.85 \%$ ), amisulpride (from $0.55 \%$ to $7.85 \%$ ), paliperidone (from $0.00 \%$ to $3.68 \%$ ), asenapine (from $0.0 \%$ to $1.60 \%$ ), iloperidone (from $0.55 \%$ to $1.04 \%$ ), zotepine (from $0.00 \%$ to $0.72 \%$ ) and blonanserine (from $0.00 \%$ to $0.40 \%$ ), as against decreased in olanzapine (from $43.72 \%$ to $41.87 \%$ ), risperidone (from $46.99 \%$ to $36.59 \%$ ), clozapine (from $43.72 \%$ to $22.34 \%$ ), lurasidone and perospirone (from $0.55 \%$ to $0.24 \%$ ) from 1998-2005 to 2006-2013 (Table 6).

\section{Disease-wise distribution of publications}

The Indian publications in AADs were studied according to the disease focused. The maximum number of drug publications were focused on schizophrenia (524 publications), followed by depression (216 publications), bipolar disorder (194 publications), movement disorder (146 publications), anxiety disorder (141 publications), insomnia (59 publications), dementia

Table 4: Share of various foreign countries in India's international collaborative publications in AADs during 1998-2013

\begin{tabular}{|c|c|c|c|c|c|c|}
\hline \multirow{2}{*}{$\begin{array}{l}\text { Collaborating } \\
\text { country }\end{array}$} & \multicolumn{3}{|c|}{ Number of international collaborative publications } & \multicolumn{3}{|c|}{ Share of international collaborative publications } \\
\hline & 1998-2005 & 2006-2013 & 1998-2013 & 1998-2005 & 2006-2013 & 1998-2013 \\
\hline USA & 12 & 68 & 80 & 48.00 & 50.00 & 49.69 \\
\hline UK & 6 & 36 & 42 & 24.00 & 26.47 & 26.09 \\
\hline Australia & 4 & 23 & 27 & 16.00 & 16.91 & 16.77 \\
\hline Canada & 0 & 14 & 14 & 0.00 & 10.29 & 8.70 \\
\hline Malaysia & 0 & 12 & 12 & 0.00 & 8.82 & 7.45 \\
\hline Israel & 3 & 8 & 11 & 12.00 & 5.88 & 6.83 \\
\hline China & 1 & 10 & 11 & 4.00 & 7.35 & 6.83 \\
\hline Germany & 2 & 8 & 10 & 8.00 & 5.88 & 6.21 \\
\hline South Korea & 1 & 9 & 10 & 4.00 & 6.62 & 6.21 \\
\hline Switzerland & 0 & 10 & 10 & 0.00 & 7.35 & 6.21 \\
\hline Thailand & 0 & 10 & 10 & 0.00 & 7.35 & 6.21 \\
\hline Japan & 0 & 9 & 9 & 0.00 & 6.62 & 5.59 \\
\hline Singapore & 0 & 9 & 9 & 0.00 & 6.62 & 5.59 \\
\hline Total of the country & 25 & 136 & 161 & & & \\
\hline
\end{tabular}

AADs: Atypical antipsychotic drugs

Table 5: Subject-wise break-up of Indian publications in AADs, 1998-2013

\begin{tabular}{|c|c|c|c|c|c|c|c|c|}
\hline \multirow[t]{2}{*}{ Subject } & \multicolumn{3}{|c|}{ Number of publications (TP) } & \multicolumn{2}{|c|}{ Activity index } & \multirow{2}{*}{$\begin{array}{c}\text { TC } \\
\text { 1998-2013 }\end{array}$} & \multirow{2}{*}{$\begin{array}{c}\text { ACPP } \\
1998-2013\end{array}$} & \multirow{2}{*}{$\begin{array}{c}\text { \%TP } \\
1998-2013\end{array}$} \\
\hline & 2003-2007 & 2008-2012 & 2003-2012 & 2003-2007 & 2008-2012 & & & \\
\hline Medicine & 116 & 755 & 871 & 59.29 & 99.38 & 1796 & 2.06 & 60.82 \\
\hline Pharmacology, toxicology and pharmaceutics & 66 & 470 & 536 & 52.56 & 100.53 & 1584 & 2.95 & 37.43 \\
\hline Neurosciences & 36 & 141 & 177 & 48.63 & 91.33 & 631 & 3.56 & 12.36 \\
\hline Chemistry & 11 & 148 & 159 & 88.59 & 106.72 & 430 & 2.70 & 11.10 \\
\hline Biochemistry, genetics and molecular biology & 18 & 129 & 147 & 127.76 & 100.61 & 426 & 2.90 & 10.27 \\
\hline Psychiatry and psychology & 24 & 76 & 101 & 185.94 & 86.27 & 305 & 3.02 & 7.05 \\
\hline Total of India & 183 & 1249 & 1432 & & & & & \\
\hline
\end{tabular}

AADs: Atypical antipsychotic drugs 
Table 6: Drug-wise break-up of Indian publications in AADs, 1998-2013

\begin{tabular}{|c|c|c|c|c|c|c|}
\hline \multirow[t]{2}{*}{ Name of drug } & \multicolumn{3}{|c|}{ Number of publications } & \multicolumn{3}{|c|}{ Share of publications } \\
\hline & 1998-2005 & 2006-2013 & 1998-2013 & 1998-2005 & 2006-2013 & 1998-2013 \\
\hline Olanzapine & 80 & 523 & 603 & 43.72 & 41.87 & 42.11 \\
\hline Risperidone & 86 & 457 & 543 & 46.99 & 36.59 & 37.92 \\
\hline Clozapine & 80 & 279 & 359 & 43.72 & 22.34 & 25.07 \\
\hline Quetiapine & 16 & 228 & 244 & 8.74 & 18.25 & 17.04 \\
\hline Aripiprazole & 4 & 158 & 162 & 2.19 & 12.65 & 11.31 \\
\hline Ziprasidone & 13 & 98 & 111 & 7.10 & 7.85 & 7.75 \\
\hline Amisulpride & 1 & 98 & 99 & 0.55 & 7.85 & 6.91 \\
\hline Paliperidone & 0 & 46 & 46 & 0.00 & 3.68 & 3.21 \\
\hline Asenapine & 0 & 20 & 20 & 0.00 & 1.60 & 1.40 \\
\hline Iloperidone & 1 & 13 & 14 & 0.55 & 1.04 & 0.98 \\
\hline Zotepine & 0 & 9 & 9 & 0.00 & 0.72 & 0.63 \\
\hline Blonanserin & 0 & 5 & 5 & 0.00 & 0.40 & 0.35 \\
\hline Lurasidone & 1 & 3 & 4 & 0.55 & 0.24 & 0.28 \\
\hline \multirow[t]{2}{*}{ Perospirone } & 1 & 3 & 4 & 0.55 & 0.24 & 0.28 \\
\hline & 183 & 1249 & 1432 & & & \\
\hline
\end{tabular}

AADs: Atypical antipsychotic drugs

(43 publications), delirium (42 publications), personality disorders (26 publications), autism (15 publications) and post-traumatic stress disorder (4 publications) during 1998-2013. The drug-wise break-up of publications under these diseases are shown in Table 7.

\section{Scientometric profile of top 20 most productive Indian organizations}

The total Indian research output in AADs was published from several organizations, of which the top 15 most productive Indian organizations have published 14-206 publications each during 1998-2013 and together contributed 50.21\% (719 publications) share in the cumulative Indian publications. The scientometric profile of these 15 Indian organizations is presented in Table 8. The average publication productivity per organization reported by the top 15 Indian organizations was 47.93 and only three organizations have registered higher output than the group average. These are National Institute of Mental Health and Neurosciences (NIMHANS), Bangalore with 206 publications, followed by Central Institute of Psychiatry, New Delhi (98 publications) and Postgraduate Institute of Medical Education and Research (PGIMER), Chandigarh (95 publications).

The average citation per paper registered by the total publications of these 15 Indian organizations was 2.14 during 1998-2013 and four Indian organizations have registered higher citation impact than the group average. They are Institute of Technology, Banaras Hindu University (BHU), and Varanasi with citation impact per paper of 6.13, followed by Panjab University, University Institute of Pharmaceutical Sciences, Chandigarh (5.53),
Dr. Ram Manohar Lohia Hospital, New Delhi (3.09) and Maharaj Medical University, Lucknow (2.24).

The average h-index value of these 15 Indian organizations was 7.13 and six organizations have achieved higher h-index value than the group's average. These are NIMHANS, Bangalore with h-index value of 17, followed by Central Institute of Psychiatry, New Delhi (12), PGIMER, Chandigarh (10), Christian Medical College, Vellore (8), Dr. Ram Manohar Lohia Hospital, New Delhi (8) and Institute of Technology, BHU, Varanasi (8).

The average share of international collaborative publications of top 15 Indian organizations was 15.40 and four Indian organizations have achieved higher international collaborative publications (ICP) share than the group's average. These are CS Maharaj Medical University, Lucknow with ICP share of $52.38 \%$, followed by Dr. Ram Manohar Lohia Hospital, New Delhi (39.13\%), Christian Medical College, Vellore (22.86\%) and NIMHANS, Bangalore (15.53\%).

\section{Media of communications}

The top 15 foreign and Indian journals contributed 343 and 268 publications in Indian AADs research, accounting for $23.95 \%$ and $18.02 \%$ share of the total Indian publications in AADs during 1998-2013. The share of Indian publications in foreign journals has increased from $22.95 \%$ to $24.10 \%$, in contrast to decrease in Indian journals from $18.03 \%$ to $18.01 \%$ from $1998-2005$ to $2006-2013$. The top 15 foreign journals reported an average citation impact per paper of 4.09, compared to 2.75 in Indian journals during 1998-2013. The journal receiving the highest citation impact per 
Table 7: Disease-wise break-up of Indian publications in AADs, 1998-2013

\begin{tabular}{|c|c|c|c|c|c|}
\hline $\begin{array}{l}\text { Disease } \\
\text { (publications) }\end{array}$ & $\begin{array}{l}\text { Drug } \\
\text { (publications) }\end{array}$ & $\begin{array}{l}\text { Disease } \\
\text { (publications) }\end{array}$ & $\begin{array}{l}\text { Disease } \\
\text { (publications) }\end{array}$ & $\begin{array}{l}\begin{array}{l}\text { Disease } \\
\text { (publications) }\end{array} \\
\end{array}$ & $\begin{array}{l}\text { Disease } \\
\text { (publications) }\end{array}$ \\
\hline \multirow[t]{14}{*}{$\begin{array}{l}\text { Schizophrenia } \\
\text { (524 publications) }\end{array}$} & Olanzapine (257) & $\begin{array}{l}\text { Movement disorders } \\
\text { (146 publications) }\end{array}$ & Olanzapine (71) & $\begin{array}{l}\text { Dementia } \\
\text { (43 publications) }\end{array}$ & Olanzapine (21) \\
\hline & Risperidone (272) & & Risperidone (69) & & Risperidone (17) \\
\hline & Clozapine (217) & & Clozapine (61) & & Clozapine (11) \\
\hline & Quetiapine (106) & & Quetiapine (37) & & Quetiapine (17) \\
\hline & Aripiprazole (83) & & Aripiprazole (28) & & Aripiprazole (5) \\
\hline & Ziprasidone (57) & & Ziprasidone (19) & $\begin{array}{l}\text { Delirium } \\
\text { (42 publications) }\end{array}$ & Olanzapine (26) \\
\hline & Amisulpride (63) & & Amisulpride (21) & & Risperidone (22) \\
\hline & Paliperidone (16) & & Paliperidone (3) & & Clozapine (10) \\
\hline & Asenapine (2) & & Asenapine (2) & & Quetiapine (10) \\
\hline & Iloperidone (4) & & Iloperidone (3) & & Aripiprazole (4) \\
\hline & Zotepine (6) & & Zotepine (3) & & Ziprasidone (3) \\
\hline & Blonanserin (2) & & Blonanserin (1) & & Blonanserin (1) \\
\hline & Lurasidone (2) & & Lurasidone (1) & $\begin{array}{l}\text { Personality disorders } \\
\text { (26 publications) }\end{array}$ & Olanzapine (11) \\
\hline & Perospirone (4) & $\begin{array}{l}\text { Anxiety disorder } \\
\text { (141 publications) }\end{array}$ & Olanzapine (64) & & Risperidone (13) \\
\hline \multirow{10}{*}{$\begin{array}{l}\text { Depression } \\
\text { ( } 216 \text { publications) }\end{array}$} & Olanzapine (105) & & Risperidone (77) & & Clozapine (7) \\
\hline & Risperidone (106) & & Clozapine (40) & & Quetiapine (9) \\
\hline & Clozapine (60) & & Quetiapine (34) & & Aripiprazole (4) \\
\hline & Quetiapine (59) & & Aripiprazole (28) & & Ziprasidone (3) \\
\hline & Aripiprazole (33) & & Ziprasidone (16) & & Amisulpride (2) \\
\hline & Ziprasidone (28) & & Amisulpride (15) & & Paliperidone (4) \\
\hline & Amisulpride (24) & & Paliperidone (4) & $\begin{array}{l}\text { Autism } \\
\text { (15 publications) }\end{array}$ & Risperidone (12) \\
\hline & & & Asenapine (2) & & Clozapine (9) \\
\hline & & & Iloperidone (3) & & Aripiprazole (7) \\
\hline & & & Blonanserin (1) & & Olanzapine (6) \\
\hline \multirow{11}{*}{$\begin{array}{l}\text { Bipolar disorder } \\
\text { (194 publications) }\end{array}$} & Olanzapine (118) & & Lurasidone (1) & & Quetiapine (4) \\
\hline & Risperidone (86) & $\begin{array}{l}\text { Insomnia } \\
\text { (59 publications) }\end{array}$ & Risperidone (32) & & Ziprasidone (4) \\
\hline & Clozapine (50) & & Clozapine (20) & $\begin{array}{l}\text { Post-traumatic Stress } \\
\text { disorder ( } 4 \text { publications) }\end{array}$ & Olanzapine (2) \\
\hline & Quetiapine (50) & & Quetiapine (16) & & Risperidone (2) \\
\hline & Aripiprazole (29) & & Aripiprazole (13) & & \\
\hline & Ziprasidone (18) & & Ziprasidone (10) & & \\
\hline & Amisulpride (14) & & & & \\
\hline & Paliperidone (4) & & & & \\
\hline & Asenapine (3) & & & & \\
\hline & Blonanserin (3) & & & & \\
\hline & Lurasidone (9) & & & & \\
\hline
\end{tabular}

paper (19.33) was Schizophrenia Research, followed by British Journal of Psychiatry (14.67), Progress in Neuro Psychopharmacology and Biological Psychiatry (9.73), Journal of Clinical Psychopharmacology (7.56), Neurology India (5.71), etc. (Table 9).

\section{High cited publications}

There are 12 high cited publications which have received more than 100 citations since the publication of the paper until April 2014. These 12 high cited publications together received 2054 citations registering an average citation per paper of 171.17. These 12 publications have received citations in the range of: 304-359 (two publications), 152-184 (three publications) and 108-135 (four publications). Of the 12 high cited publications, five are reviews and seven articles. These 12 high cited publications are published in eight professional journals: Journal of Controlled Release (five publications), Lancet, World Psychiatry, British Journal of Psychiatry, Biological Psychiatry, Pharmacological 
Table 8: Scientometric profile of top 15 Indian organizations in AADs, 1998-2013

\begin{tabular}{|c|c|c|c|c|c|c|}
\hline Name of Institute & TP & TC & ACPP & h-index & ICP & \%ICP \\
\hline NIMHANS, Bangalore & 206 & 429 & 2.08 & 17 & 32 & 15.53 \\
\hline Central Institute of Psychiatry, New Delhi & 98 & 208 & 2.12 & 12 & 3 & 3.06 \\
\hline PGIMER, Chandigarh & 95 & 193 & 2.03 & 10 & 6 & 6.32 \\
\hline Kasturba Medical College, Manipal & 36 & 11 & 0.31 & 4 & 3 & 8.33 \\
\hline Christian Medical College, Vellore & 35 & 75 & 2.14 & 8 & 8 & 22.86 \\
\hline AlIMS, New Delhi & 35 & 54 & 1.54 & 7 & 1 & 2.86 \\
\hline GB Pant Hospital, New Delhi & 34 & 50 & 1.47 & 6 & 2 & 5.88 \\
\hline Panjab University, University Institute of Pharmaceutical Sciences, Chandigarh & 32 & 177 & 5.53 & 6 & 2 & 6.25 \\
\hline Jawaharlal Nehru Technological University, Hyderabad & 30 & 58 & 1.93 & 6 & 0 & 0.00 \\
\hline University of Mysore & 25 & 29 & 1.16 & 5 & 1 & 4.00 \\
\hline Dr. Ram Manohar Lohia Hospital, New Delhi & 23 & 71 & 3.09 & 8 & 9 & 39.13 \\
\hline CS Maharaj Medical University, Lucknow & 21 & 47 & 2.24 & 5 & 11 & 52.38 \\
\hline Indira Gandhi Medical College & 20 & 17 & 0.85 & 2 & 0 & 0.00 \\
\hline Institute of Technology, BHU, Varanasi & 15 & 92 & 6.13 & 8 & 1 & 6.67 \\
\hline Dr. Reddy’s Lab Ltd., Hyderabad & 14 & 26 & 1.86 & 3 & 0 & 0.00 \\
\hline Total of 15 organizations & 719 & 1537 & 2.14 & 7.13 & 79 & 15.40 \\
\hline Total of the country & 1432 & & & & & \\
\hline Share of 15 organizations in country output & 50.21 & & & & & \\
\hline
\end{tabular}

TP: Total publications, TC: Total citations, ACPP: Average citation per paper, ICP: International collaborative publications, NIMHANS: National Institute of Mental Health and Neurosciences, PGIMER: Postgraduate Institute of Medical Education and Research, AlIMS: All India Institute of Medical Sciences, AADs: Atypical antipsychotic drugs

Table 9: Top 15 foreign and Indian journals contributing to Indian AADs research during 1998-2013

\begin{tabular}{|c|c|c|c|c|c|c|c|c|c|c|c|}
\hline \multirow[t]{2}{*}{ Foreign journals } & \multicolumn{3}{|c|}{ TP } & \multirow{2}{*}{$\begin{array}{c}\text { TC } \\
1998- \\
2013\end{array}$} & \multirow[t]{2}{*}{ ACPP } & \multirow[t]{2}{*}{ Indian journals } & \multicolumn{3}{|c|}{ TP } & \multirow{2}{*}{$\begin{array}{c}\text { TC } \\
1998- \\
2013\end{array}$} & \multirow{2}{*}{ ACPP } \\
\hline & $\begin{array}{l}1998- \\
2005\end{array}$ & $\begin{array}{l}2006- \\
2013\end{array}$ & $\begin{array}{l}1998- \\
2013\end{array}$ & & & & $\begin{array}{l}1998- \\
2005\end{array}$ & $\begin{array}{l}2006- \\
2013\end{array}$ & $\begin{array}{l}1998- \\
2013\end{array}$ & & \\
\hline $\begin{array}{l}\text { Journal of Neuropsychiatry and } \\
\text { Clinical Neurosciences }\end{array}$ & 0 & 59 & 59 & 91 & 1.54 & Indian Journal of Psychiatry & 0 & 56 & 56 & 104 & 1.86 \\
\hline $\begin{array}{l}\text { Australian and New Zealand } \\
\text { Journal of Psychiatry }\end{array}$ & 18 & 26 & 44 & 176 & 4.00 & Indian Journal of Pharmacology & 12 & 25 & 37 & 103 & 2.19 \\
\hline German Journal of Psychiatry & 5 & 26 & 31 & 23 & 0.74 & Indian Drugs & 6 & 10 & 16 & 47 & 2.94 \\
\hline $\begin{array}{l}\text { Primary Care Companion to the } \\
\text { Journal of Clinical Psychiatry }\end{array}$ & 0 & 28 & 28 & 44 & 1.57 & Indian Journal of Medical Sciences & 2 & 13 & 15 & 75 & 5.00 \\
\hline Journal of ECT & 3 & 23 & 26 & 44 & 1.69 & Neurology India & 8 & 6 & 14 & 80 & 5.71 \\
\hline General Hospital Psychiatry & 1 & 23 & 24 & 94 & 3.92 & Asian Journal of Chemistry & 2 & 11 & 13 & 35 & 2.69 \\
\hline Journal of Clinical Psychiatry & 7 & 16 & 23 & 111 & 4.83 & $\begin{array}{l}\text { International Journal of Pharmtech } \\
\text { Research }\end{array}$ & 0 & 13 & 13 & 44 & 3.38 \\
\hline $\begin{array}{l}\text { International Journal of } \\
\text { Pharmacy and Pharmaceutical } \\
\text { Science }\end{array}$ & 0 & 18 & 18 & 51 & 2.83 & $\begin{array}{l}\text { International Journal of } \\
\text { Pharmaceutical Sciences Review } \\
\text { and Research }\end{array}$ & 0 & 13 & 13 & 50 & 3.85 \\
\hline Asian Journal of Psychiatry & 0 & 16 & 16 & 7 & 0.44 & $\begin{array}{l}\text { Indian Journal of Psychological } \\
\text { Medicine }\end{array}$ & 0 & 13 & 13 & 7 & 0.54 \\
\hline $\begin{array}{l}\text { Journal of Clinical } \\
\text { Psychopharmacology }\end{array}$ & 1 & 15 & 16 & 121 & 7.56 & Journal of Postgraduate Medicine & 2 & 10 & 12 & 36 & 3.00 \\
\hline Schizophrenia Research & 3 & 12 & 15 & 290 & 19.33 & $\begin{array}{l}\text { Journal of Chemical and } \\
\text { Pharmaceutical Research }\end{array}$ & 0 & 12 & 12 & 5 & 0.42 \\
\hline British Journal of Psychiatry & 3 & 9 & 12 & 176 & 14.67 & $\begin{array}{l}\text { Indian Journal of Pharmaceutical } \\
\text { Sciences }\end{array}$ & 1 & 10 & 11 & 74 & 6.73 \\
\hline $\begin{array}{l}\text { Progress in Neuro } \\
\text { Psychopharmacology and } \\
\text { Biological Psychiatry }\end{array}$ & 1 & 10 & 11 & 107 & 9.73 & $\begin{array}{l}\text { International Journal of Chemtech } \\
\text { Research }\end{array}$ & 0 & 11 & 11 & 66 & 6.00 \\
\hline Der Pharmaacia Lettre & 0 & 10 & 10 & 16 & 1.60 & $\begin{array}{l}\text { Research Journal of Pharmacy and } \\
\text { Technology }\end{array}$ & 0 & 11 & 11 & 2 & 0.18 \\
\hline $\begin{array}{l}\text { Psychiatry and Clinical } \\
\text { Neurosciences }\end{array}$ & 0 & 10 & 10 & 53 & 5.30 & $\begin{array}{l}\text { Research Journal of Pharmaceutical, } \\
\text { Biological and Chemical Sciences }\end{array}$ & 0 & 11 & 11 & 8 & 0.73 \\
\hline Total of 15 journals & 42 & 301 & 343 & 1404 & 4.09 & Total of 15 journals & 33 & 224 & 258 & 736 & 2.75 \\
\hline Total of the country & 183 & 1249 & 1432 & & & Total of the country & 183 & 1249 & 1432 & & \\
\hline $\begin{array}{l}\text { Share of top } 15 \text { journals in } \\
\text { country output }\end{array}$ & 22.95 & 24.10 & 23.95 & & & $\begin{array}{l}\text { Share of top } 15 \text { journals in country } \\
\text { output }\end{array}$ & 18.03 & 18.01 & 18.02 & & \\
\hline
\end{tabular}

TP: Total publications, TC: Total citations, ACPP: Average citation per paper, AADs: Atypical antipsychotic drugs 
Table 10: List of high cited publications in Indian AADs research during 1998-2013

\begin{tabular}{|c|c|c|c|c|}
\hline Name of authors & Title of the article & Source & Affiliations & $\begin{array}{l}\text { Number of } \\
\text { citations }\end{array}$ \\
\hline $\begin{array}{l}\text { Mundargi RC, Babu VR, } \\
\text { Rangaswamy V, Patel P, } \\
\text { Aminabhavi TM }\end{array}$ & $\begin{array}{l}\text { Nano/micro technologies for } \\
\text { delivering macromolecular } \\
\text { therapeutics using } \\
\text { poly (d, I-lactide-co-glycolide) and } \\
\text { its derivatives (Review) }\end{array}$ & $\begin{array}{l}\text { Journal of } \\
\text { Controlled Release } \\
2008 ; 125(3): 193-20\end{array}$ & $\begin{array}{l}\text { Reliance Life Sciences Pvt. Ltd., } \\
\text { Mumbai, India }\end{array}$ & 359 \\
\hline $\begin{array}{l}\text { Patel V, Flisher AJ, } \\
\text { Hetrick S, McGorry P }\end{array}$ & $\begin{array}{l}\text { Mental health of young } \\
\text { people: A global public-health } \\
\text { challenge (Review) }\end{array}$ & $\begin{array}{l}\text { Lancet 2007;369 (9569): } \\
1302-1313\end{array}$ & $\begin{array}{l}\text { London School of Hygiene and } \\
\text { Tropical Medicine, London, UK; } \\
\text { Sangath Center, Alto Porvorim, } \\
\text { Goa, India; etc. }\end{array}$ & 304 \\
\hline $\begin{array}{l}\text { Venkateswarlu V, } \\
\text { Manjunath K }\end{array}$ & $\begin{array}{l}\text { Preparation, characterization } \\
\text { and in vitro release kinetics } \\
\text { of clozapine solid lipid } \\
\text { nanoparticles (Article) }\end{array}$ & $\begin{array}{l}\text { Journal of } \\
\text { Controlled Release } \\
\text { 2004;95 (3):627-638 }\end{array}$ & $\begin{array}{l}\text { Kakatiya University, } \\
\text { NDDS Laboratory, Univ. } \\
\text { Coll. of Pharmaceutical } \\
\text { Sci., Warangal-506 009, } \\
\text { Andhra Pradesh, India }\end{array}$ & 184 \\
\hline $\begin{array}{l}\text { De Hert M, } \\
\text { Correll CU, Bobes J, } \\
\text { Cetkovich-Bakmas M, Cohen } \\
\text { DAN, Asai I, Detraux J, } \\
\text { Gautam S, Möller HJ, Ndetei } \\
\text { DM, Newcomer JW, Uwakwe } \\
\text { R, Leucht S }\end{array}$ & $\begin{array}{l}\text { Physical illness in patients with } \\
\text { severe mental disorders. I. } \\
\text { Prevalence, impact of medications } \\
\text { and disparities in health } \\
\text { care (Review) }\end{array}$ & $\begin{array}{l}\text { World Psychiatry } \\
\text { 2011;10(1):52-77 }\end{array}$ & $\begin{array}{l}\text { University Psychiatric Center, } \\
\text { Catholic University Leuven, } \\
\text { Leuvensesteenweg, Belgium; } \\
\text { Japanese Society of Transcultural } \\
\text { Psychiatry, Medical College, Jaipur, } \\
\text { India; Psychiatric Centre, Medical } \\
\text { College, Jaipur, India; etc. }\end{array}$ & 158 \\
\hline $\begin{array}{l}\text { Kaur IP, Bhandari R, } \\
\text { Bhandari S, Kakkar V }\end{array}$ & $\begin{array}{l}\text { Potential of solid lipid } \\
\text { nanoparticles in brain } \\
\text { targeting (Review) }\end{array}$ & $\begin{array}{l}\text { Journal of } \\
\text { Controlled Release } \\
\text { 2008;127(2):97-109 }\end{array}$ & $\begin{array}{l}\text { Panjab University, University } \\
\text { Institute of Pharmaceutical } \\
\text { Sciences, Chandigarh,; } \\
\text { A.S.B.A.S.J.S.M. College Of } \\
\text { Pharmacy, Ropar, India }\end{array}$ & 152 \\
\hline $\begin{array}{l}\text { Manjunath } \mathrm{K} \text {, } \\
\text { Venkateswarlu V }\end{array}$ & $\begin{array}{l}\text { Pharmacokinetics, } \\
\text { tissue distribution and } \\
\text { bioavailability of clozapine } \\
\text { solid lipid nanoparticles after } \\
\text { intravenous and intraduodenal } \\
\text { administration (Article) }\end{array}$ & $\begin{array}{l}\text { Journal of } \\
\text { Controlled Release } \\
\text { 2005;107(2):215-228 }\end{array}$ & $\begin{array}{l}\text { NDDS Laboratory, University } \\
\text { College of Pharmaceutical } \\
\text { Sciences, Kakatiya University, } \\
\text { Warangal } 506009 \text {, } \\
\text { Andhra Pradesh, India }\end{array}$ & 147 \\
\hline $\begin{array}{l}\text { Khanna S, Vieta E, } \\
\text { Lyons B, Grossman F, } \\
\text { Eerdekens M, Kramer M }\end{array}$ & $\begin{array}{l}\text { Risperidone in the treatment } \\
\text { of acute mania: Double-blind, } \\
\text { placebo-controlled study (Article) }\end{array}$ & $\begin{array}{l}\text { British Journal } \\
\text { of Psychiatry } \\
\text { 2005;187(SEPT):229-234 }\end{array}$ & $\begin{array}{l}\text { Psychiatric Clinic, Vasant Vihar, } \\
\text { New Delhi, India; Department of } \\
\text { Psychiatry, Hospital Clinic, University } \\
\text { of Barcelona, Barcelona, Spain, et al. }\end{array}$ & 139 \\
\hline $\begin{array}{l}\text { Arvindakshan M, } \\
\text { Sitasawad S, Debsikdar V, } \\
\text { Ghate M, Evans D, Horrobin } \\
\text { DF, Bennett C, Ranjekar } \\
\text { PK, Mahadik SP }\end{array}$ & $\begin{array}{l}\text { Essential polyunsaturated fatty } \\
\text { acid and lipid peroxide levels in } \\
\text { never-medicated and medicated } \\
\text { schizophrenia patients (Article) }\end{array}$ & $\begin{array}{l}\text { Biological Psychiatry } \\
\text { 2003;53(1):56-64 }\end{array}$ & $\begin{array}{l}\text { National Chemical Laboratory, } \\
\text { Division of Biochemical Sciences, } \\
\text { Pune, India; National Center for Cell } \\
\text { Sciences, Pune, India; Kripamayee } \\
\text { Inst. of Mental Health, Miraj, India; } \\
\text { Department of Psychiatry, MIMER } \\
\text { Medical College, Talegaon, India; } \\
\text { Laxdale Research Institute, Stirling, } \\
\text { United Kingdom, et al. }\end{array}$ & 139 \\
\hline $\begin{array}{l}\text { Sonkusare SK, Kaul CL, } \\
\text { Ramarao P }\end{array}$ & $\begin{array}{l}\text { Dementia of Alzheimer's disease } \\
\text { and other neurodegenerative } \\
\text { disorders - Memantine, a new } \\
\text { hope (Review) }\end{array}$ & $\begin{array}{l}\text { Pharmacological } \\
\text { Research } \\
2005 ; 51(1): 1-17\end{array}$ & $\begin{array}{l}\text { Natl. Inst. Pharmaceutical Educ. } \\
\text { R., Dept. of Pharmacology and } \\
\text { Toxicology, S.A.S. Nagar, } 160062 \text {, } \\
\text { Mohali, India }\end{array}$ & 135 \\
\hline $\begin{array}{l}\text { Agnihotri SA, } \\
\text { Aminabhavi TM }\end{array}$ & $\begin{array}{l}\text { Controlled release of clozapine } \\
\text { through chitosan microparticles } \\
\text { prepared by a novel } \\
\text { method (Article) }\end{array}$ & $\begin{array}{l}\text { Journal of } \\
\text { Controlled Release } \\
\text { 2004;96(2):245-259 }\end{array}$ & $\begin{array}{l}\text { Drug Delivery Division, } \\
\text { Ctr. of Excellence in Poly. } \\
\text { Science, Karnatak University, } \\
\text { Dharwad - } 580003 \text {, India }\end{array}$ & 118 \\
\hline $\begin{array}{l}\text { Smulevich AB, Khanna S, } \\
\text { Eerdekens M, Karcher K, } \\
\text { Kramer M, Grossman F }\end{array}$ & $\begin{array}{l}\text { Acute and continuation risperidone } \\
\text { monotherapy in bipolar mania: } \\
\text { A } 3 \text { weeks placebo-controlled } \\
\text { trial followed by a } 9 \text { weeks } \\
\text { double-blind trial of risperidone } \\
\text { and haloperidol (Article) }\end{array}$ & $\begin{array}{l}\text { European } \\
\text { Neuropsychopharmacology } \\
\text { 2005;15(1):75-84 }\end{array}$ & $\begin{array}{l}\text { Natl. Mental Health Research } \\
\text { Center, Moscow, Russia, Russian } \\
\text { Federation; Department of } \\
\text { Psychiatry, Natl. Inst. Mental } \\
\text { Health. N., Bangalore, India, } \\
\text { India, et al. }\end{array}$ & 111 \\
\hline $\begin{array}{l}\text { Banerjee R, Bhatt PM, } \\
\text { Ravindra NV, Desiraju GR }\end{array}$ & $\begin{array}{l}\text { Saccharin salts of active } \\
\text { pharmaceutical ingredients, their } \\
\text { crystal structures, and increased } \\
\text { water solubilities (Article) }\end{array}$ & $\begin{array}{l}\text { Crystal Growth } \\
\text { and Design } \\
2005 ; 5(6): 2299-2309\end{array}$ & $\begin{array}{l}\text { School of Chemistry, University of } \\
\text { Hyderabad, Hyderabad } 500046 \text {, } \\
\text { India; Informatics Division, GVK } \\
\text { Biosciences }\end{array}$ & 108 \\
\hline
\end{tabular}


Research, European Nueropsychopharmacology and Crystal Growth and Design (one paper each). The 12 high cited publications involve 20 Indian organizations, including Kakatiya University, University College of Pharmaceutical Science, Warangal (two publications), Reliance Life Sciences Pvt. Ltd., Mumbai (one paper), NIMHANS, Bangalore (one paper), Sangath Center, Goa (one paper), Medical College, Jaipur (one paper), Panjab University, University Institute of Pharmaceutical Science, Chandigarh (one paper), National Institute of Pharmaceutical Education and Research, Mohali (one paper), etc. The 12 high cited publications involve five international collaborative publications and two national collaborated publications (Table 10).

\section{SUMMARY}

In AADs research, India has produced 1432 publications during 1998-2013, which increased from 9 to 216 publications from the year 1998-2013, registering an annual average growth rate of $22.76 \%$. India's global publication rank was $10^{\text {th }}$ among the 15 most productive countries with global publication share of 2.86\% during 1998-2012. India's global publication share and rank increased from $1.01 \%$ to $3.91 \%$ and from $12^{\text {th }}$ to $8^{\text {th }}$ from $1998-2005$ to 2006-2013. The citation impact per paper registered by Indian publications in AADs was 2.43, which decreased from 3.14 to 2.32 from 1998-2005 to 2006-2013. Of the total publications, $35.89 \%$ of the total publications did not get any citations (zero citation) and $64.11 \%$ publications were cited one or more times. Of the cited publications, only $0.84 \%$ of the publications (receiving more than 100 citations) contributed $22.71 \%$ citations share, as against $49.090 \%$ publications (receiving citations from 1 to 10 ) contributing $35.89 \%$ citations share. Only $11.24 \%$ of the total Indian publications were internationally collaborative during 1998-2013, which decreased from $13.66 \%$ to $10.89 \%$ from 1998-2005 to 2006-2013. Among the leading foreign collaborative partners, USA contributed the largest share of $49.69 \%$ during 1998-2013, followed by UK $(26.09 \%)$, Australia (16.77\%), Canada (8.70\%), Malaysia (7.45\%), Israel (6.83\%), China (6.83\%), etc. Among the subjects, medicine contributed the largest share of $60.82 \%$ during 1998-2013, followed by pharmacology, toxicology and pharmaceutics $(37.43 \%)$, neurosciences $(12.36 \%)$, chemistry $(11.10 \%)$, biochemistry, genetics and molecular biology (10.27\%) and psychiatry and psychology (7.05\%). Research activity has increased in medicine, pharmacology, toxicology and pharmaceutics, neurosciences and chemistry, as against decrease in biochemistry, genetics and molecular activity and psychiatry and psychology from 1998-2005 to 2006-2013. The most widely studied drug was olanzapine with $42.11 \%$ publication share, followed by risperidone $(37.92 \%)$, clozapine $(25.07 \%)$, quetiapine $(17.04 \%)$, aripiprazole $(11.31 \%)$, ziprasidone (7.75\%), amisulpride (6.91\%), paliperidone (3.21\%), asenapine $(1.40 \%)$, iloperidone $(0.98 \%)$, zotepine $(0.63 \%)$, blonanserine $(0.35 \%)$, lurasidone $(0.24 \%)$ and perospirone $(0.24 \%)$ during $1998-2013$. The research interest in the use of these drugs have increased in quetiapine, aripiprazole, ziprasidone, amisulpride, paliperidone, asenapine, iloperidone, zotepine and blonanserine, as against decrease in olanzapine, risperidone, clozapine, lurasidone and perospirone from 1998-2005 to 2006-2013. Among the diseases reported for the use of these drugs, the largest number of publications (524) were in schizophrenia, followed by depression (216 publications), bipolar disorder (194 publications), movement disorder (146 publications), anxiety disorder (141 publications), insomnia (59 publications), dementia (43 publications), delirium (42 publications), personality disorders (26 publications), autism (15 publications) and post-traumatic stress disorder (4 publications) during 1998-2013. The top 15 most productive Indian organizations together account for $50.21 \%$ (719 publications) share to the cumulative Indian publications output in AADs research during 1998-2013. The largest number of publications (206 publications) were contributed by NIMHANS, Bangalore, followed by Central Institute of Psychiatry, New Delhi (98 publications) and PGIMER, Chandigarh (95 publications), etc. Among various journals contributing to AADs research, the top 15 foreign and Indian journals contributed accounts for $23.95 \%$ and $18.02 \%$ share of the total Indian publications during 1998-2013. The share of Indian publications in foreign journals has increased from $22.95 \%$ to $24.10 \%$, in contrast to decrease in Indian journals from $18.03 \%$ to $18.01 \%$ from $1998-2005$ to $2006-2013$.

\section{REFERENCES}

1. Treatment of mental disorders, 21 April 2014. Available from: http://www. en.wikipedia.org/wiki/Treatment_of_mental_disorders. [Last accessed on 2014 Apr 20].

2. Antipsychotic medications 1996-2014. Available from: http://www. medicinenet.com/script/main/art.asp?articlekey=26299. [Last accessed on 2014 Apr 20].

3. Antipsychotic medicines. Available from: http://www.patient.co.uk/health/ antipsychotic-medicines. [Last accessed on 2014 Apr 20].

4. Preskorn SH. Antipsychotic drug development in the pre-human-genome era: A full circle. J Psychiatr Pract 2001;7:209-13.

5. Atypical antipsychotic, 2 May 2014. Available from: http://www. en.wikipedia.org/wiki/Atypical_antipsychotic. [Last accessed on 2014 Apr 20].

6. López-Muñoz F, Shen WW, Pae CU, Moreno R, Rubio G, Molina JD, et al. Trends in scientific literature on atypical antipsychotics in South Korea: A bibliometric study. Psychiatry Investig 2013;10:8-16. 
7. López-Muñoz F, Castle D, Shen W, Moreno R, Huelves L, Pérez-Nieto M, et al. The Australian contribution to the literature on atypical antipsychotic drugs: A bibliometric study. Australas Psychiatry 2013;21:343-5.

8. López-Muñoz F, Rubio G, Molina JD, Shen WW, Pérez-Nieto MA, Moreno R, et al. Mapping the scientific research on atypical antipsychotic drugs in Spain: a bibliometric assessment. Actas Esp Psiquiatr 2013;41:349-60.

9. López-Muñoz F, Chung AK, Shen WW, Huelves L, Noriega C, et al. A bibliometric study of scientific research on second-generation antipsychotic drugs in Hong Kong. Clin Exp Pharmacol 2013;3:124.

10. Gupta BM, Har K, Avinash K. Dementia research in India: A scientometric analysis of research output during 2002-11. Ann Libr Inf Stud 2011;59:280-8.
11. Gupta BM, Bala A. Alzheimer's disease research in India: A scientometric analysis of publications output during 2002-11. Res Neurol 2013;11 pages. Article ID 204542, DOI: 10.5171/2013.204542.

12. Gupta BM, Bala A. Parkinson disease in India: An analysis of publications output during 2002-11. Int J Nutr Pharmacol Neurol Dis 2013;20:71-8.

13. Gupta BM, Bala A. Epilepsy research in India: A scientometric analysis of publications output during, 2002-11. Ann Neurosci 2013;20(2). DOI:10.5214/ans.0972.7531.200209.

14. Gupta BM, Bala A. A scientometrics approach to schizophrenia research in India: An analysis of publications output during 2002-11. Asian J Psychiatr 2013;6:292-8. 